DOI: 10.34015/2523-4552.2019.4.11

УдК 342.6

Труба Р. М., аспірант Науково-дослідного інституту публічного права ORCID: 0000-0003-3656-0061

\title{
КОМПЕТЕНЦІЯ ДЕРЖАВНОГО БЮРО РОЗСЛІДУВАНЬ
}

Державне бюро розслідувань $\epsilon$ правоохоронним органом, який розпочав свою діяльність порівняно нещодавно. Тому, окремі аспекти його правового статусу на сьогодні все ще не отримали належного розкриття у науковій літературі. Одним із таких питань $є$ компетенція Державного бюро розслідувань. У даній статті досліджено компетенцію Державного бюро розслідувань. Проаналізовано їі специфіку у порівнянні із компетенцією інших правоохоронних органів. Встановлено, які функції було передано Державному бюро розслідувань від інших правоохоронних органів. Визначено особливості компетенції Державного бюро розслідувань.

Ключові слова: Державне бюро розслідувань; компетенція; компетенція Державного бюро розслідувань.

Государственное бюро расследований является правоохранительным органом, который начал свою деятельность сравнительно недавно. Поэтому, отдельные аспекты его правового статуса на сегодня все еще не получили должного раскрытия в научной литературе. Одним из таких вопросов является компетенция Государственного бюро расследований. В данной статье исследовано компетенцию Государственного бюро расследований. Проанализировано его специфику по сравнению с компетенцией других правоохранительных органов. Установлено, какие функции были переданы Государственному бюро расследований от других правоохранительных органов. Определены особенности компетенции Государственного бюро расследований.

Ключевые слова: Государственное бюро расследований компетенция; компетенция Государственного бюро расследований.

Постановка проблеми. Державне бюро розслідувань $є$ новоутвореним правоохоронним органом, який здійснює свою діяльність 3 метою запобігання, виявлення, припинення, розкриття та розслідування злочинів, віднесених до його компетенції. Враховуючи, що даний орган фактично розпочав свою діяльність в 2017 році, кількість досліджень, присвячених засадам його функціонування на сьогодні $\epsilon$ незна- чною. Одним із питань, яке потребує особливої наукової уваги, є компетенція даного органу, адже саме ця характеристика визначає, чим відрізняється діяльність Державного бюро розслідувань від діяльності інших органів, а також свідчить про те, наскільки важливим є створення такої структури в нашій державі. Також варто враховувати те, що Державне бюро розслідувань було наділене частиною функцій, які до цього на- 
лежали іншим правоохоронним органам, а тому важливо встановити, якими $є$ ці функції, і яким чином співвідноситься компетенція даного органу із компетенцією інших правоохоронних органів у даному аспекті. Це свідчить про актуальність дослідження питання компетенції Державного бюро розслідувань та організації його діяльності.

Аналіз останніх досліджень і публікацій. Питання компетенції Державного бюро розслідувань у тій чи іншій мірі торкались фактично усі дослідники діяльності даного органу. Але разом із тим, варто враховувати, що чисельність таких праць на сьогодні $\epsilon$ незначною, і відповідні дослідження переважно не мали комплексний характер. Серед дослідників відзначимо внесок таких, як: А. С. Атаманчук, О. Ю. Бусол, А. Л. Ворожко, В. О. Гринюк, Ю. М. Грошевий, Б. В. Деревянко, О. О. Джабурія, А. А. Єлісєєва, О. Р. Звоненко, В. С. Зеленецький, О. В. Ільченко, В. В. Комашко, О. В. Курганський, В. І. Литвиненко, Л. М. Лобойко, О. Р. Михайленко, М. А. Погорецький, Д. Б. Сергєєва, Є. Д. Скулиш, О. С. Старенький, О. Ю. Татаров, Л. Д. Удалова, В. І. Цимбалюк, I. В. Цюприк, В. І. Чечерський, О. В. Шамара, О. М. Юрченко. Проте, очевидно, що питання компетенції Державного бюро розслідувань та організації його діяльності потребує подальших наукових досліджень.

Постановка завдання. Мета статті: 1) дослідити компетенцію Державного бюро розслідувань; 2) встановити, чим компетенція Державного бюро розслідувань відрізняється від компетенції інших правоохоронних органів; 3) визначити особливості компетенції Державного бюро розслідувань.
Виклад основного матеріалу. у Великому тлумачному словнику сучасної української мови компетенція визначається, як добра обізнаність із чим-небудь; коло повноважень певної організації або особи, а термін «компетентний» тлумачиться у значенні який має достатні знання в якій-небудь галузі; який 3 чимнебудь добре обізнаний; тямущий; який грунтується на знанні; кваліфікований; який має певні повноваження; повноправний, повновладний $[1$, c. 560$]$. Тобто, у такому значенні під компетенцією Державного бюро розслідувань варто розуміти коло повноважень даного органу. Повноваження органу виконавчої влади роз'яснюються в Указі Президента України «Про заходи щодо впровадження Концепції адміністративної реформи в Україні» від 22.07.1998 № 810/98 [10], як закріплені за органом виконавчої влади права і обов'язки (в тому числі обов'язки нести відповідальність за наслідки виконання повноважень - так звані «юрисдикційні» обов'язки). Також, у даному нормативно-правовому акті встановлено, що для визначення певного обсягу повноважень, закріпленого за кожним органом виконавчої влади відповідно до покладених на нього завдань і функцій, застосовується поняття «компетенція», а центральне місце і переважну частину серед повноважень будь-якого органу виконавчої влади складають державно-владні повноваження, тобто повноваження щодо прийняття обов'язкових до виконання рішень і забезпечення їх здійснення тими, кому вони адресовані.

Схожим чином повноваження розглядаються і у науковій літератуpi. Так, на думку О.Я. Лазор й 
О. Д. Лазора, компетенція - це сукупність встановлених в офіційній (юридичній чи неюридичній) формі прав і обов'язків: тобто повноважень будь-якого органу чи посадової особи, які визначають можливості цього органу або посадової особи приймати обов'язкові до виконання рішення, організовувати та контролювати їх виконання, вживати в необхідних випадках заходів відповідальності [8, c. 90]. Тобто, дослідники також розглядають поняття «компетенції» у контексті повноважень органу. Подібним чином визначає компетенцію О. Ю. Оболенський, який тлумачить дане питання як межі ведення, обов'язок виконання певних завдань і функцій органу державної влади: як владні повноваження, той чи інший обсяг державної діяльності, покладений на даний орган, або коло передбачених правовим актом питань, шо може вирішувати цей орган [3, c. 156]. Дослідник також для роз'яснення сутності поняття «компетенція» вживає формулювання «владні повноваження», при цьому роз'яснюючи їх як межі ведення, обов'язок виконання певних завдань і функцій органу державної влади.

Таким чином, термін «компетенція» вживається у науковій літературі для об'єднання таких понять, як «повноваження», «завдання» та «функції». За допомогою такого терміну окреслюються права та обов'язки того чи іншого суб'єкта у певній сфері, на яку такий суб'єкт має вплив. Тож, компетенція Державного бюро розслідувань - це сукупність його повноважень, закріплених в офіційній формі відповідно до покладених на нього завдань і функцій, які визначають можливості Державного бюро розслідувань приймати обов'язкові до виконання рішення, організовувати та контролювати їх виконання.

Так, деякі з повноважень Державного бюро розслідувань перейшли до даного органу безпосередньо від органів прокуратури, які тепер позбавлені всіх своїх слідчих функцій на користь Державного бюро розслідувань України [5, с. 170]. У науковій літературі поширена також думка, що Державне бюро розслідувань взяло на себе всі функції Військової прокуратури та слідчі функції Міністерства внутрішніх справ, Служби безпеки України i Національного антикорупційного бюро України, проте такий підхід є хибним. Перехід повноважень до Державного бюро розслідувань відбувся лише від органів прокуратури, а з іншими правоохоронними органами відбулось розмежування компетенції, внаслідок якого компетенція Державного бюро розслідувань була окреслена повноваженнями щодо запобігання, виявлення, припинення, розкриття та розслідування злочинів, які вчиняються вищими посадовими особами, службовими особами Національного антикорупційного бюро України чи Спеціалізованої антикорупційної прокуратури, або військовими.

Повноваження Державного бюро розслідувань визначені в статті 6 Закону України «Про Державне бюро розслідувань» від 12.11.2015 № 794-VIII [9], і до них віднесено наступні: 1) участь у формуванні та реалізації державної політики у сфері протидії злочинності; 2) здійснення інформаційно-аналітичних заходів щодо встановлення системних причин та умов проявів організованої злочинності та інших видів злочинності, протидію яким віднесено 
до компетенції Державного бюро розслідувань; 3) припинення і розкриття злочинів у межах його компетенції; 4) здійснення оперативнорозшукової діяльності та досудового розслідування злочинів, віднесених до підслідності Державного бюро розслідувань; 5) здійснення розшуку осіб, які переховуються від слідства та суду за злочини, розслідування яких віднесено до підслідності Державного бюро розслідувань; 6) використання гласних і негласних штатних та позаштатних працівників на підставах та в порядку, встановлених законом; 7) розробка і затвердження методики розслідування окремих видів злочинів; 8) вжиття заходів щодо відшкодування завданих державі збитків і шкоди; 9) вжиття заходів для повернення в Україну з-за кордону коштів та іншого майна, одержаних внаслідок вчинення злочинів, віднесених до підслідності Державного бюро розслідувань; 10) доступ до інформаційних систем органів державної влади, самостійне створення інформаційних систем; 11) організація забезпечення особистої безпеки осіб рядового i начальницького складу, державних службовців Державного бюро розслідувань, захист осіб, які беруть участь у кримінальному судочинстві, від протиправних посягань; 12) забезпечення роботи з підготовки, перепідготовки та підвищення кваліфікації працівників Державного бюро розслідувань; 13) здійснення виконання запитів про надання правової допомоги, які надійшли від компетентних органів іноземних держав; 14) розроблення пропозиції до проектів міжнародних договорів України та забезпечення дотримання і виконання зобов'язань, взятих за міжнародними договорами України; 15) здійснення співробітництва 3 поліцейськими та іншими відповідними органами іноземних держав відповідно до законів та міжнародних договорів України; 16) забезпечення відповідно до законодавства додержання режиму захищеної законом таємниці та іншої інформації 3 обмеженим доступом; 17) звітування про свою діяльність та інформування суспільства про результати своєї роботи; 18) вжиття заходів щодо виявлення необгрунтованих активів та збору доказів їх необгрунтованості; 19) здійснення інших повноважень. Із даного переліку можна зробити наступні висновки: по-перше, переважна більшість повноважень характеризують Державне бюро розслідувань як орган досудового розслідування та окреслюють його права та обов'язки у процесі запобігання, виявлення, припинення, розкриття та розслідування злочинів; по-друге, окремі повноваження стосуються участі Державного бюро розслідувань у державній політиці у сфері протидії злочинності та міжнародному співробітництві; по-третє, особливу групу повноважень Державного бюро розслідувань становлять повноваження, пов'язані з роботою із персоналом даного органу.

Щодо першої виділеної нами групи повноважень, то В.В. Долежан звертає увагу на те, що специфіка компетенції Державного бюро розслідувань обумовлена двома факторами: статусом посадових осіб, які обвинувачуються у вчиненні злочинів (від екс-Президента України до інших посадових осіб, які посідають відповідальне місце у службовій ієрархії згідно із частиною 4 статті 216 Кримінального процесуального ко- 
дексу України [7]), а також характером і тяжкістю [4, с. 16]. Саме ці два критерії дозволяють розрізняти компетенцію Державного бюро розслідувань від компетенції інших правоохоронних органів - Служби безпеки України, Національної поліції, слідчих органів, що здійснюють розслідування порушень податкового законодавства, Національного антикорупційного бюро України. Так, відповідно до частини 4 статті 216 Кримінального процесуального кодексу України [7] слідчі органи Державного бюро розслідувань здійснюють розслідування злочинів, вчинених Президентом України, повноваження якого припинено, Прем'єрміністром України, членом Кабінету Міністрів України, першим заступником та заступником міністра, членом Національної ради України 3 питань телебачення і радіомовлення, Національної комісії, що здійснює державне регулювання у сфері ринків фінансових послуг, Національної комісії з цінних паперів та фондового ринку, Антимонопольного комітету України, Головою Державного комітету телебачення і радіомовлення України, Головою Фонду державного майна України, його першим заступником та заступником, членом Центральної виборчої комісії, народним депутатом України, Уповноваженим Верховної Ради України 3 прав людини, Директором Національного антикорупційного бюро України, Генеральним прокурором, його першим заступником та заступником, Головою Національного банку України, його першим заступником та заступником, Секретарем Ради національної безпеки і оборони України, його першим заступником та заступником, Постійним Предста- вником Президента України в Автономній Республіці Крим, його першим заступником та заступником, радником або помічником Президента України, Голови Верховної Ради України, Прем'єр-міністра України, суддею, працівником правоохоронного органу, особою, посада якої належить до категорії «А», крім випадків, коли досудове розслідування цих злочинів віднесено до підслідності Національного антикорупційного бюро України [7].

Щодо груп повноважень, які стосуються участі Державного бюро розслідувань у державній політиці у сфері протидії злочинності та міжнародному співробітництві та повноважень, пов'язаних із роботою із персоналом даного органу, зробимо висновок про те, що вони відповідають аналогічним повноваженням, якими наділяються інші правоохоронні органи. Отже у даному аспекті компетенція Державного бюро розслідувань не відрізняється від компетенції інших правоохоронних органів.

Разом із тим, варто враховувати, що поява нових правоохоронних органів традиційно породжує суперечки щодо компетенції. Так, згідно зі статтею 5 Закону України «Про Державне бюро розслідувань» від 12.11.2015 № 794-VIII [9], Державне бюро розслідувань вирішує завдання із запобігання, виявлення, припинення, розкриття і розслідування злочинів, які вчиняються вищими посадовими особами, службовими особами Національного антикорупційного бюро України чи Спеціалізованої антикорупційної прокуратури, або військовими. Іншими словами, потенційна кількість справ, підслідних Державному бюро розслідувань, $\epsilon$ порівняно невеликою При цьому, 
як відзначає В. Б. Деревянко, стосовно переважної більшості категорій потенційних підслідних (за можливим винятком військовослужбовців та службових осіб Національного антикорупційного бюро України) застосовується правило пріоритетності досудового розслідування цих злочинів детективами Національного антикорупційного бюро України $[2$, c. 80]. Іншими словами, компетенцію Державного бюро розслідувань та Національного антикорупційного бюро України законодавцем розмежовано на користь пріоритетності дій детективів останнього, але при цьому справи за злочинами, учиненими співробітниками Національного антикорупційного бюро України, розслідуються в досудовому порядку працівниками Державного бюро розслідувань.

Співвідносячи компетенцію Державного бюро розслідувань та Національної поліції, звернемось до статті 23 Закону України «Про Національну поліцію» від 02.07.2015 № 580-VIII [11]. Серед переліку повноважень Національної поліції, звернемо увагу на те, що даний орган здійснює досудове розслідування кримінальних правопорушень у межах визначеної підслідності та здійснює оперативно-розшукову діяльність відповідно до закону, як і Державне бюро розслідувань. У даному контексті варто погодитись із В.Б. Деревянком у тому, що відмінність компетенції проявляється $\mathrm{y}$ здійсненні Національною поліцією досудового розслідування кримінальних правопорушень, скоєних різними особами, в той час, як Державне бюро розслідувань розслідує злочини, які вчиняються вищими посадовими особами, службовими особа- ми Національного антикорупційного бюро України чи Спеціалізованої антикорупційної прокуратури, або військовими [2, с. 81]. Отже, і Державне бюро розслідувань, і Національна поліція здійснюють досудове розслідування та оперативно-розшукову діяльність, проте виключно тих злочинів, які віднесено до підслідності кожного із органів.

Порівнюючи компетенцію Державного бюро розслідувань та органів прокуратури, передусім зазначимо, що деякі 3 повноважень Державного бюро розслідувань України перейшли до даного органу безпосередньо саме від органів прокуратури. Отже в даному аспекті можна зробити висновок про те, що компетенція цих органів на сьогодні фактично не перетинається, адже органи прокуратури були позбавлені тих повноважень, які отримало Державне бюро розслідувань. Проте, варто звернути увагу на те, що згідно зі статтею 25 Закону України «Про прокуратуру» від 14.10.2014 № 1697VII [12], органи прокуратури здійснюють нагляд за додержанням законів органами, що провадять оперативно-розшукову діяльність, дізнання, досудове слідство. Хоча у даному аспекті компетенція Державного бюро розслідувань та органів прокуратури не перетинається, варто відзначити, що органи прокуратури здійснюють функції контролю щодо Державного бюро розслідувань.

Співвідносячи компетенцію Державного бюро розслідувань та Служби безпеки України, Законом України «Про Службу безпеки України» від 25.03.1992 № 2229-XII [13] до компетенції останньої також входить попередження, виявлення, припинення корупції та організованої 
злочинної діяльності у сфері управління i економіки. Як відзначає В. Б. Деревянко, якщо для Державного бюро розслідувань такі повноваження $є$ основними, то для Служби безпеки України такі повноваження все ж є додатковими у порівнянні із захистом державного суверенітету, конституційного ладу, територіальної цілісності, економічного, науково-технічного й оборонного потенціалу України, законних інтересів держави та прав громадян від розвідувально-підривної діяльності іноземних спеціальних служб, посягань 3 боку окремих організацій, груп та осіб, а також забезпеченням охорони державної таємниці [2, с. 81]. Тому, у цьому аспекті хоча й спостерігається близькість компетенції, проте дані органи не вступають щодо цього у конфлікт. У разі, якщо злочини, які вчиняються вищими посадовими особами, службовими особами Національного антикорупційного бюро України чи Спеціалізованої антикорупційної прокуратури, або військовими несуть загрозу для державного суверенітету, конституційного ладу, територіальної цілісності, економічного, науково-технічного і оборонного потенціалу України, законних інтересів держави та прав громадян, $\epsilon$ наслідком розвідувально-підривної діяльності іноземних спеціальних служб, посягань з боку окремих організацій, груп та осіб, а також пов'язані із державною таємницею, вони є підслідними Службі безпеки України. У разі, якщо ні - їх припинення, розкриття і розслідування здійснює Державне бюро розслідувань.

Найбільш близькою $є$ компетенція Державного бюро розслідувань та Національного антикорупційного бюро України, адже обидва органи здійснюють попередження, виявлення, припинення, розслідування та розкриття злочинів, віднесених до їх підслідності, а також запобігання вчиненню нових. Проте, варто враховувати, що підслідність у обох органів є різною - якщо здійснює Державне бюро розслідувань розслідує виключно злочини, які вчиняються вищими посадовими особами, службовими особами Національного антикорупційного бюро України чи Спеціалізованої антикорупційної прокуратури, або військовими, то Національне антикорупційне бюро України - корупційні злочини, якими вважаються злочини, передбачені частиною 2 статті 191, частиною 2 статті 262, частиною 2 статті 308, частиною 2 статті 312 , частиною 2 статті 313, частиною 2 статті 320 , частиною1 статті 357 , частиною 2 статті 410, у випадку їх вчинення шляхом зловживання службовим становищем, а також злочини, передбачені статтями 354, 364, 3641, 3652, 368-370 Кримінального кодексу України [6]. Іншим критерієм розмежування компетенції Державного бюро розслідувань та Національного антикорупційного бюро України $\epsilon$ те, що останньому підслідні злочини, розмір предмета яких або завданої ними шкоди в п'ятсот і більше разів перевищує розмір прожиткового мінімуму для працездатних осіб, встановленої законом на час вчинення злочину, якщо злочин вчинено службовою особою державного органу, правоохоронного органу, військового формування, органу місцевого самоврядування (пункт 2 частини 5 статті 216 Кримінального процесуального кодексу України [7]). Тож, враховуючи характер корупційних 
злочинів, можна спрогнозувати, що інтереси Державного бюро розслідувань та Національного антикорупційного бюро України постійно перетинатимуться, проте, Кримінальний процесуальний кодекс України [7] проводить чітку межу між компетенцією обох органів. Зі змісту статті 216 Кримінального процесуального кодексу України [7] слідує висновок, що Державне бюро розслідувань розслідує злочини визначеної категорії осіб, окрім віднесених до підслідності Національного антикорупційного бюро України, а отже компетенція цих органів також $є$ розмежованою.

Отже, компетенція Державного бюро розслідувань у окремих аспектах $\epsilon$ близькою до компетенції інших правоохоронних органів. Проте, чинним законодавством повноваження таких органів $\epsilon$ чітко розмежованими, а тому компетенція Державного бюро розслідувань здебільшого не конкурує з компетенцією інших правоохоронних органів.

Висновки. Таким чином, зробимо висновок про наступні особливості, які притаманні компетенції Державного бюро розслідувань та які дозволяють розрізняти компетенцію Державного бюро розслідувань та компетенцію інших правоохоронних органів:
1) компетенція Державного бюро розслідувань включає повноваження, які перейшли до цього органу безпосередньо від органів прокуратури, та $\epsilon$ близькими до повноважень інших правоохоронних органів, проте підслідність злочинів, яким запобігає та які виявляє, припиняє, розкриває та розслідує даний орган, свідчить про те, що компетенція Державного бюро розслідувань не конкурує з компетенцією інших правоохоронних органів;

2) компетенція Державного бюро розслідувань охоплює питання, пов'язані із його правами та обов'язками у процесі запобігання, виявлення, припинення, розкриття та розслідування злочинів; участю Державного бюро розслідувань у державній політиці у сфері протидії злочинності та міжнародному співробітництві; повноваженнями, пов'язаними 3 роботою із персоналом даного органу;

3) компетенція Державного бюро розслідувань поширюється на запобігання, виявлення, припинення, розкриття та розслідування злочинів, які вчиняються вищими посадовими особами, службовими особами Національного антикорупційного бюро України чи Спеціалізованої антикорупційної прокуратури, або військовими.

\section{Список використаних джерел}

1. Великий тлумачний словник сучасної української мови / [гол. ред. В. Т. Бусел, редактори-лексикографи: В. Т. Бусел, М. Д. Василега-Дерибас, О. В. Дмитрі$€$ в, Г. В. Латник, Г. В. Степенко]. Киїі-Ірпінь : Перун, 2005. 1728 с.

2. Деревянко Б. В. Державне бюро розслідувань як новий державний орган зі спеціальною компетенцією. Правовий часопис Донбасу. 2019. № 2 (67). С. 78-84 .

3. Державне управління та державна служба : словник-довідник уклад. О. Ю. Оболенськнй. Київ : КНЕУ, 2005. 480 с.

4. Долежан В. В. Проблеми компетенції Державного бюро розслідувань. Державне бюро розслідувань: на шляху розбудови: матер. Міжнар. наук.-практ. конф. 
(м. Одеса, 16 червня 2018 р.) / редкол.: Г. О.Ульянова (голова ред.), В. М. Дрьомін, Є. Л. Стрельцов [та ін.] ; НУ "ОЮА". Одеса : Юридична література, 2018. С. 15-17.

5. Звоненко О. Р. Створення Державного бюро розслідувань (проблемні питання). Збірник тез доповідей студентів, аспірантів та здобувачів - учасників 73-ї звітної конференції Одеського національного університету імені I. I. Мечникова, 25 квітня 2017 р., м. Одеса. Секція економічних і правових наук / ОНУ ім. I. І. Мечникова, ЕПФ; відп. ред. А. В. Смітюх. Одеса : Фенікс, 2017. С. 170-172.

6. Кримінальний кодекс України: Закон України від 05.04.2001 № 2341-III. Biдомості Верховної Ради України. 2001. № 25-26. ст.131

7. Кримінальний процесуальний кодекс України: Закон України від 13.04.2012 № 4651-VI. Відомості Верховної Ради України. 2013. № 9-10. № 11-12. № 13. ст. 88.

8. Лазор О. Місцеве управління: поняття, терміни, визначення : навч. посіб. 2-е вид., переробл. і доп. Київ : Дакор, 2006. 352 с.

9. Про Державне бюро розслідувань. Закон України від 12.11.2015 № 794-VIII. Відомості Верховної Ради України. 2016 р. № 6. стор. 5. стаття 55.

10. Про заходи щодо впровадження Концепції адміністративної реформи в Україні: Указ Президента України від 22.07.1998 № 810/98. Офіційний вісник України. 1999 р. № 21. стор. 32. стаття 943. код акта 7616/1999.

11. Про Національну поліцію: Закон України від 02.07.2015 № 580-VIII. Відомості Верховної Ради. 2015. № 40-41. ст. 379.

12. Про прокуратуру: Закон України від 14.10.2014 № 1697-VII. Відомості Верховної Ради. 2015. № 2-3. ст. 12.

13. Про Службу безпеки України: Закон України від 25.03.1992 № 2229-XII. Вiдомості Верховної Ради України. 1992. № 27. ст. 38.

\section{References}

1. Busel, V. T. (Red). (2005). Velikij tlumachnij slovnik suchasnoyi ukrayinskoyi movi. Kiyiv, Irpin: VTF «Perun» [in Ukrainian].

2. Derevyanko, B. V. (2019). Derzhavne byuro rozslIduvan yak noviy derzhavniy organ zI spetslalnoyu kompetentsIEyu. Pravoviy chasopis Donbasu, 2, 78-84 [in Ukrainian].

3. Dolezhan, V. V. (2018). Problemi kompetentsIYi Derzhavnogo byuro rozsliduvan. Derzhavne byuro rozslIduvan: na shlyahu rozbudovi: mater. MIzhnar. nauk.prakt. konf. 16 chervnya 2018 r. NU "OYuA". Odesa : Yuridichna literatura [in Ukrainian].

4. Zvonenko, O. R. (2017). Stvorennya Derzhavnogo byuro rozslIduvan (problemnI pitannya). ZbIrnik tez dopovIdey studentIv, aspIrantIv ta zdobuvachIv 25 kvItnya 2017 r. ONU Im. I. I. Mechnikova, Odesa : FenIks [in Ukrainian].

5. Lazor, 0. (2006). MIstseve upravlInnya: ponyattya, termIni, viznachennya : navch. posIb. 2-e vid., pererobl. i dop. Kiyiv: Dakor [in Ukrainian].

\section{$\boldsymbol{R}$. Truba, Postgraduate research fellow Institute of Public Law ORCID: 0000-0003-3656-0061}

\section{Competence of the State Bureau of Investigation}

The State Bureau of Investigation of Ukraine is a law enforcement agency that started its operations recently. Therefore, some aspects of its legal status have not yet been properly disclosed in the scientific literature. One such issue is the 
competence of the State Bureau of Investigation of Ukraine. This article examines the competence of the State Bureau of Investigation of Ukraine. Its specificity is compared with the competence of other law enforcement agencies. It was established what functions were transferred to the State Investigation Bureau of Ukraine from other law enforcement agencies. The features of the competence of the State Bureau of Investigation of Ukraine are determined. It is determined that the competence of the State Bureau of Investigation is the totality of its powers, assigned in an official form in accordance with its tasks and functions, which determine the ability of the State Bureau of Investigation to make binding decisions, organize and monitor their execution. It is concluded that features that are within the competence of the State Bureau of Investigation are: 1) the competence of the State Bureau of Investigation includes powers that have been transferred to this body directly from the prosecuting authorities, but are close to the powers of other law enforcement agencies, but are consistent with the crime of crime. detects, suspends, discloses and investigates this body, certifies that the competence of the State Bureau of Investigation does not compete with that of other law enforcement agencies; 2) the competence of the State Bureau of Investigation covers issues related to its rights and obligations in the process of prevention, detection, termination, disclosure and investigation of crimes; the involvement of the State Bureau of Investigation in public policy on crime and international cooperation; powers related to working with the staff of the body; 3 ) the competence of the State Bureau of Investigation extends to the prevention, detection, termination, disclosure and investigation of crimes committed by senior officials, officials of the National Anti-Corruption Bureau of Ukraine or the Specialized Anti-Corruption Prosecutor's Office, or the military.

Keywords: State Bureau of Investigation of Ukraine; competence; competence of the State Bureau of Investigation of Ukraine. 